\title{
Feminist Translation Matters: Reading Fashion, Materiality, and Revolution in the English-Language Translations of Marie Chauvet's La danse sur le volcan'
}

\author{
Siobhan Meï \\ siobhanander@umass.edu \\ University of Massachusetts Amherst, U.S.
}

\begin{abstract}
Like feminist translation studies, recent scholarship at the intersections of feminist and fashion theories has offered new ways of thinking about the history of modernity, the body, and communication in interpersonal and transnational spheres. Fashion and translation share similar attributes in popular thought - both are ubiquitous and often perceived as superficial. Both are often relegated to the realm of the feminine in which the labor of self-fashioning or translation is viewed as derivative, shallow, or intellectually disengaged. Drawing together feminist knowledge from translation and fashion studies to form a transdisciplinary framework, this paper explores the role of dress-its production, materiality, and history-in the context of two English-language translations of the novel La danse sur le volcan (1957) by Haitian author Marie Chauvet (1916-1973). In its analysis of the translation history of La danse into English, this article suggests that a transnational feminist literary translation praxis necessitates a sustained engagement with the material and imagined lives of objects in the longue durée, particularly fashion items such as scarves and dresses.
\end{abstract}

Keywords: fashion, Chauvet, material culture, Haitian Revolution, feminist translation, African diaspora studies.

Aspectos de la traducción feminista: una lectura de la moda, la materialidad y la revolución en las traducciones al inglés de La danse sur le volcan, de Marie Chauvet

\section{Resumen}

Al igual que la traductología feminista, los estudios recientes en las intersecciones de las teorías feministas y de la moda ofrecen nuevas formas de pensar la historia de la modernidad, el cuerpo y la comunicación en ámbitos interpersonales y transnacionales. La moda y la traducción comparten atributos similares en el imaginario popular: ambas son ubicuas y muchas veces se perciben como superficiales. Ambas suelen quedar relegadas al ámbito de lo femenino, en el que las labores de

1 This article belongs to "Refashioning History: Women as Sartorial Storytellers," a dissertation in-progress supported by the University of Massachusetts Amherst. 
self-fashioning, o construcción de la propia imagen pública, y la traducción se consideran derivaciones, triviales o desligadas de lo intelectual. Uniendo el conocimiento feminista de la traducción y los estudios sobre moda para conformar un marco transdisciplinario, este artículo explora el rol del vestido (su producción, materialidad e historia) en el contexto de dos traducciones al inglés de la novela $\mathrm{La}$ danse sur le volcan (1957), de la autora haitiana Marie Chauvet (1916-1973). En su análisis de la historia de la traducción de La danse al inglés, este artículo señala que una praxis de traducción literaria feminista transnacional requiere un relacionamiento sostenido con las vidas materiales e imaginadas de los objetos en la longue durée, en particular con artículos de la moda, como bufandas y vestidos.

Palabras clave: moda, Chauvet, cultura material, Revolución Haitiana, traducción feminista, estudios de la diáspora africana.

\section{Question de matière en traduction féministe : lire la mode, la matérialité et la révolution dans les traductions vers l'anglais de La danse sur le volcan par Marie Chauvet}

\section{Résumé}

Tout comme dans les études de la traduction féministe, les explorations récentes à l'intersection de la théorie féministe et de la théorie de la mode offrent de nouvelles façons de penser l'histoire de la modernité, du corps, et de la communication dans les sphères interpersonnelles et transnationales. La mode et la traduction partagent des attributs semblables dans la pensée populaire, toutes deux sont omniprésentes et souvent considérées comme superficielles. Toutes deux étant souvent reléguées au domaine de la féminité dans le sens où le travail de traduction ou de stylisme sont perçus comme dérivatifs ou intellectuellement frivoles. En juxtaposant les savoirs féministes des études de la traduction et de la mode pour créer un cadre transdisciplinaire, cet article a pour but d'examiner le rôle de la mode - sa production, matérialité et son histoire- dans le contexte de deux traductions du roman, La danse sur le volcan (1957) par l'auteure haïtienne, Marie Chauvet (1916-1973). Dans son analyse de l'histoire de la traduction vers l'anglais de La danse, cet article suggère qu'une pratique de la traduction littéraire transnationale féministe nécessite un engagement soutenu avec les vies matériaux et imaginées des objets sur une longue durée, particulièrement pour les objets de mode comme les écharpes et les robes.

Mots clés: mode, Chauvet, culture matérielle, Révolution haïtienne, traduction féministe, études africaines et diasporiques. 


\section{Introduction}

In Fabiola Jean-Louis's 2018 photographic art piece "Marie Antoinette is dead," a Black woman stares tranquilly ahead as she reclines in a chaise longue positioned in front of heavy, gilded, baroque curtains (Figure 1). The woman's creased blue petticoat is trimmed with a pink chintz pattern that billows out beyond the frame of the image - in one hand (against her ribboned bodice) she cradles a Black doll in a West-African-style print dress while the other delicately encloses a nosegay of bluewhite flowers. "Marie Antoinette is Dead" is part of a series by Jean-Louis titled "Re-Writing History: Paper Gowns and Photographs," which honors Black femininity and style in its revision of the exclusionary aesthetics of European fine art traditions in which Black women are often portrayed as nameless figures or as exotified objects of sexual fantasy and desire. In "Re-Writing History," Black and mixed-race women subjects appropriate poses evocative of modern and early modern aristocratic women's portraiture, holding flowers or fans and standing or sitting in front of opulent drapes or works of art. Interwoven - sometimes quite literally — within the material fineries commonly associated with European nobility, are objects, images, and sculptures (such as a three-dimensional lynching scene boxed within the bodice of a gown), that summon histories of enslavement and colonialism in the West. In this series, Jean-Louis uses the medium of photography to blur the boundaries between past and present, asserting a continuous, transhistorical celebration of the Black feminine body.

Recent artistic explorations of the intimate relationship between dress and the politics of belonging, such as "Re-Writing History," traverse disciplinary boundaries and in doing so situate national archives within larger, less visible networks of global communications, trade, and travel. The relevance of fashion to global cultural studies is becoming increasingly obvious, particularly as fashion gains traction in the public sphere as a serious form of artistic expression and scholarly inquiry. The Metropolitan Museum of Art in New York recently held its first exhibit on fashion since 1944 (Items: Is Fashion Modern? 2017-2018), and fashion studies, as an approach to thinking modernity and the racialized, gendered body, has given rise to a rich and diverse field of cultural analysis. ${ }^{2}$ Feminist fashion theorists, in particular, have highlighted the significance of fashion as an embodied ritual. Clothing, by its very design, always gestures beyond itself to the human body, actively or subtly participating in a narrative of self-representation (de la Haye, 1999; Entwistle \& Wilson, 2001; Wilson, 2003). In these discourses, dress is a "thing" in the material culture sense, meaning that even as an inanimate object, an article of clothing has a social life and often, a historical trace (Appadurai, 1988; Brown, 2003). Its fundamental role in the public construction of identity makes fashion a critical lens for exploring concepts of political visibility and citizenship, particularly within systems of economic and social oppression. It is for this reason that while fashion can be explored within the broader frame of material culture, its role as a quotidian language of identity and social status means that fashion has a unique history and position within the world of material things.

Just as feminist fashion theorists actively explored the tensions between body and garment through the lenses of gender, race, and sexuality in the late twentieth century, historical and philosophical perceptions of the relationship

2 See Walker, 2017; Brevik-Zender, 2014; Cheng, 2013; Miller, 2009; Lehmann, 2000; Wilson, 1985. 


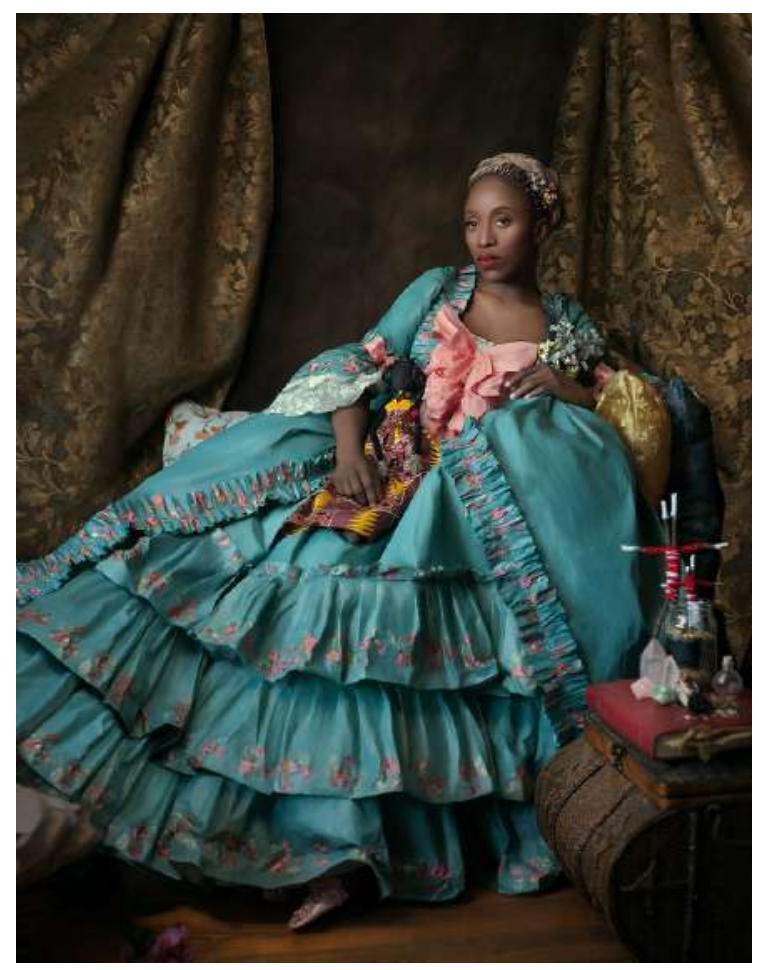

Figure 1. Jean-Louis, Fabiola. "Marie Antoinette is Dead," from the series Re-Writing History: Paper Gowns and Photographs. Archival pigment print, unframed. 2017. http://www.fabiolajeanlouis.com/rewriting-historycolor-prints

between source text and translation emerged as a significant area of inquiry for feminist translation scholars in the 1980s and 1990s. These scholars were interested in interrogating the ways in which gender constructs underwrote the hierarchical source/translation, original/ copy dynamic that characterized thinking around cultural production in the West (Chamberlain, 1988; Simon, 1996; Flotow, 1997). These discourses have led to sustained critical examinations of issues of authorship, reproduction, and labor as they pertain to and inform the role of translation as communication across linguistic and cultural differences. In this way, feminist approaches to both translation and fashion studies have generated new ways of thinking about the relationship between the racialized, gendered body and its modes of representation.
This article draws together feminist knowledge from translation studies and fashion studies to form a transdisciplinary framework for the exploration of material circulation, self-representation, and creative labor in the context of the Atlantic world. A methodological approach such as this one permits the interpretation of not only the material histories of fashion objects but also the imagined lives of these objects as they travel through modes of cultural transmission such as literary translation. Through a close reading of the sartorial politics and translation history of the novel $\mathrm{La}$ Danse sur le volcan (1957) by renowned Haitian author, Marie Chauvet (also known as Marie Vieux-Chauvet), ${ }^{3}$ this chapter responds to the following questions: How is fashion translated? How are fashion's opacities and complex histories transformed and informed by translation? How does the language and materiality of fashion historically intersect with processes of translation in the Americas? In responding to these questions, I suggest that a feminist praxis in the context of literary translation necessitates a sustained engagement with the material lives of objects in the longue durée, particularly those fashion items that serve as the material markers of diasporic knowledge, culture, and historical memory.

\section{Re-writing history: women as sartorial storytellers}

In the seventeenth century, the French Royal Academy placed portraiture second only to history painting in their hierarchy of artistic

3 Many of the recent republications of Marie Chauvet's work bear the name Marie Vieux-Chauvet; "Vieux" is the author's maiden name. Marie Chauvet (sans Vieux) is how the author referred to herself during her publishing career and thus it is the name I will use when referring to the author in this article. For more on the naming of Marie Chauvet see Jean-Charles, 2017. 
genres. This classification speaks to the important social function of portraiture in reinforcing standards of taste and beauty and celebrating powerful or virtuous subjects deemed worthy of emulation (West, 2004). As Simon Gikandi discusses in Slavery and the Culture of Taste (2011), the formation of the modern, cosmopolitan subject (exemplified and celebrated through artistic genres such as portraiture) necessitated a conceptual (and in the case of fine art-visual) separation between the commerce of slavery and metropolitan cultures of taste and social civility. Gikandi addresses the ways in which slavery contributed to the formation of what he calls "the interiorized realm of the European experience" in which values such as rationality and sensibility were invoked in opposition to the supposed alterity and barbarism of African cultures and Afro-descendant peoples (Gikandi, 2011, p. 8). Though racial difference was actively produced within genres of art, performance, and literature as part of the project of European modernity, the economy of slavery as it was connected to the production of European wealth and material finery often operates as an absent presence within fine art traditions such as portraiture.

At the time that Elisabeth Vigée-Lebrun painted her 1788-9 portrait of Marie Antoinette (Figure 2), the French colony of Saint-Domingue (now known as Haiti) was the richest in the world, producing millions of pounds of raw sugar, cotton, and coffee for trade and distribution by the French empire. The economic system of slavery thus haunts this portrait of the French queen - the luxurious, red folds of fabric in the painting, the heavy gold tassels on Marie Antoinette's dress, even the rose that hangs delicately from her ivory hand, all evoke a serene, sumptuary power. This portrait exemplifies how white femininity was aesthetically manufactured in relation to Black alterity in the late eighteenth century: Marie Antoinette's material wealth, and thus her access to high fashion, was in many ways contingent on the close relationship between the European slave trade and expanding global textile markets linking Southeast Asia, Africa, Europe, and its New World colonies. Thus, while the queen's portrait artist Vigée-Lebrun-one of the few eighteenth-century women artists to become a member of the elite Académie royale de peinture et de sculpture - challenged certain patriarchal norms of artistic production in the long nineteenth century (Sherif, 1996), her participation in the glorification of Marie Antoinette through the latter's relationship to material fineries historically contextualizes a process through which white women can gain power within a modern patriarchal social system. That is, by accessing material wealth and manipulating standards of beauty and taste as they are constructed through white racial supremacy.

Jean-Louis's artistic photograph "Marie Antoinette is Dead" reconfigures the historical significance of Marie Antoinette, whose death is typically associated with the dominant narrative of the French Revolution in which modern democratic principles, such as individual liberty, were defined in opposition to monarchical rule and not necessarily to other systems of social subjugation, such as slavery. "Marie Antoinette is Dead" is thus not just a statement of historical fact, but an expression of a transhistorical aesthetic that centers legacies of Black beauty and Black self-fashioning while highlighting how these legacies are connected to collective struggles for Black freedom in the eighteenth and nineteenth centuries. As a Haitian-born artist, Jean-Louis has her own relationship to these histories, central among them, the Haitian Revolution (1791-1804), in which enslaved peoples and their descendants rose up successfully against the French empire, establishing the first independent Black state in the Western Hemisphere. 


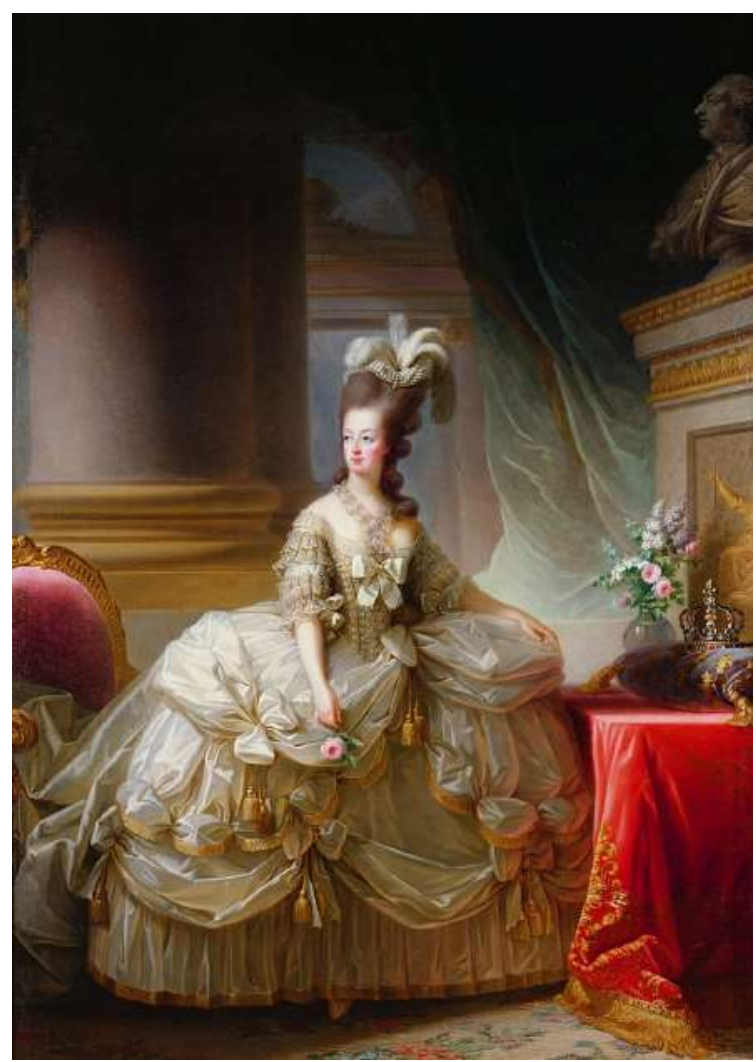

Figure 2. Vigée-Lebrun, Elisabeth Louise. Portrait of Marie-Antoinette. 1778-9. Oil on Canvas. Vienna: Kunsthistorisches Musum. Republished with permission from KHM-Museumsverband.

Considered as one of the most politically radical events in modern Western history, the Haitian Revolution, according to Laurent Dubois, "was both a local and a global event, a true world-historical moment in ways that are increasingly acknowledged today" (2016, par. 9 ). With growing interest in the role of the Haitian Revolution as one of the most impactful challenges to modern European definitions of citizenship and human rights, it is crucial to acknowledge the work of Haitian women authors, scholars, and artists, such as Jean-Louis, who show how women were creating their own definitions of what it meant to be human and to be free in in the eighteenth- and nineteenth-century Atlantic world. Author Marie Chauvet's 1957 novel, La Danse sur le volcan, re-issued in the original French in 2005 and recently re-translated into English, shows how citizenship and women's self-fashioning were linked during this powder-keg moment in Haitian history. In the novel, Chauvet's rich descriptions of women's period dress reveal how competing understandings of womanhood, femininity, and physical beauty were very much a part of the struggle for freedom and political visibility in late eighteenth-century Saint-Domingue.

Born in Port-au-Prince in 1916, Marie Chauvet is one of Haiti's most celebrated writers, despite the relative inaccessibility of her literary oeuvre for most of the second half of the twentieth century. The daughter of a Jewish émigré from the Virgin Islands and a Haitian senator and ambassador, Chauvet was a member of the Haitian bourgeois "mulatto"4 class and is considered a member of the "occupation generation" of Haitian writers in that she was born at the beginning of the 19 year occupation of Haiti by the United States military (1915-1934). This context informs the major themes of her literary oeuvre, which include the exploitation of the natural environment, the intersections of nationalism and colorism, and formations of racialized gender in Haiti. Chauvet is the author of several novels and plays. Among them, Amour, Colère, Folie (Love, Anger, Madness) (1968, trans. 2010) is a searing trilogy that describes life under the successive dictatorships (1957-1986) of François "Papa Doc" Duvalier and his son, Jean-Claude "Baby Doc" Duvalier. Amour, Colère, Folie was retracted not long after its publication in 1968 at the request of Chauvet, who feared for the

4 The Haitian use of the world "milat" ("mulatto") is tied to wealth rather than phenotype. In describing this term, Michel-Rolph Trouillot (1990) cites the Haitian proverb "Nèg rich se milat, milat pòv se nèg" ("The rich black man is a mulatto, a poor mulatto is a black") (p. 120). 
safety of her family. In the same year, Chauvet divorced her husband and left Haiti for exile in New York City, where she remarried and lived until her death in 1973.

In analyzing La Danse sur le volcan through the lens of its English-language translation history, this article responds to and participates in what Régine Michelle Jean-Charles (2017) has called the "Chauvet turn" in the study of Haitian literature. In her article "Naming, Claiming, and Framing Marie Chauvet" Jean Charles examines how critical approaches to Chauvet's work have historically focused on the myths that surround - and often become the focus of - Chauvet's literary legacy. These discourses surrounding Chauvet's work have produced a dominant critical narrative that centers the so-called "silencing" of Marie Chauvet's literary voice. ${ }^{5}$ Using an intersectional approach, Jean-Charles suggests that the mythification of Chauvet and her work offers a better understanding of the context of reception of Chauvet's oeuvre than it does of Chauvet herself: "...the problem of myths and mythification powerfully intersects with interpretations of Black women's identity in ways that infringe on personhood and subjectivity" (p. 54). Drawing on Jean-Charles analysis of myth, in this article I consider the impacts of translation on Chauvet's oeuvre and legacy. Translation, like myth, "powerfully intersects" with interpretations of identity and is also critical, as Brent Hayes Edwards (2011) shows in his

5 Some of the historical events that inform this discourse include: the retraction and halt in publication of Chauvet's works after the initial release of Amour, colère, folie in 1968, the circulation of clandestine copies of Chauvet's works in places such as Haiti, France, and the United States, and the eventual rogue republication of Amour, colère, folie by an Albanian feminist press in 2003. For more on the publication history of Chauvet's works see Spear, 2015. scholarship on Black transnational culture, to the creation of diasporic political, intellectual, and artistic communities and movements. Considering Chauvet in translation, particularly through the frame of feminist translation, is thus to situate her legacy in the world of Haitian letters while simultaneously acknowledging how she-and her translatorsparticipate in transnational conversations concerning the formation and representation of Afro-diasporic identities the Age of Revolutions and beyond.

\section{Marie Chauvet: fashioning the feminine in pre-Revolutionary Haiti}

Though often categorized as "la seule femme" (Vitiello, 1999, par. 4) among some of the major Haitian intellectuals and activists of the of the 1940s, 50s and 60s, such as Jacques Stephen Alexis, Jacques Roumain, and René Philoctète, Marie Chauvet's connections to feminist authors in Haiti and France serve to situate her work within a global community of twentieth-century women writers. As one of the objectives of this article is to signal the ways in which a feminist translation praxis shapes the reception of La danse sur le volcan in its English version, it is important to highlight briefly the ways in which Chauvet herself was connected to both local and transnational channels of feminist thinking. Though she did not, as Kaiama L. Glover has shown, have clearly expressed identarian ties to any feminist movement in Haiti or abroad, gender justice is central to her critique of Haitian social politics (Glover, 2013).

Chauvet's depictions of state violence in the form of sexual violation in the context of the novel Amour, for example, fictionalizes according to some critics, the real-life assault of journalist and feminist organizer Yvonne Hakim-Rimpel (Spear, 2015). One of the 
founders of the "Ligue feminine d'action sociale" in 1915, a group dedicated to championing the interests of working-class women in Haiti, Hakim-Rimpel openly denounced the brutalities committed by the tonton makout (the Duvalier regime's infamous paramilitary organization) in her public writing and was severely punished for it-she was tortured and left to die in a street in Pétionville in 1958. Hakim-Rimpel survived, though it took nearly 25 years of local and international pressure and the departure of Jean-Claude Duvalier from Haiti in 1986, for the regime's role in the affair to be officially acknowledged (Claude-Narcisse, 1997).

In addition to Chauvet's engagement with legacies of feminist activism in her fiction, Chauvet was in contact with feminist writers outside of Haiti, specifically Simone de Beauvoir, with whom Chauvet corresponded regularly between April 1967 and September 1972. In her essay, "The Letters of Marie Chauvet and Simone de Beauvoir: A Critical Introduction," Régine Isabelle Joseph explores their epistolary relationship, which begins with Chauvet asking Beauvoir to read her manuscripts and to eventually recommend and submit her work (including Amour, colère, folie) to the esteemed Parisian publishing house Gallimard. Joseph suggests that these epistolary interactions - in which Chauvet rhetorically appeals to Beauvoir as a fellow woman writer-is evidence of "global feminism in practice," and a form of "compagnonnage" in which women authors sought out and constructed political and intellectual communities transnationally (Joseph, 2015, p. 38).

Chauvet's practice of forging relationships with feminist writers - within her fiction and through personal and professional communications - is echoed within one of the central feminist challenges presented in La danse sur le volcan: how do people, often from radically different social and cultural backgrounds, communicate their understandings of what it means to be a woman within the context of racist heteropatriarchy? A Bildungsroman, La danse traces the political awakening of its protagonist Minette, a musical prodigy, to the horrific realities of enslavement in colonial Saint-Domingue in the years leading up to the Revolution. ${ }^{6}$ Minette and her younger sister Lise, are described in the novel as "mestive" or mixed-race - her mother, Jasmine, who was formerly enslaved, is now a member of the free "mulatto" class and her father was a white plantation owner. Minette becomes the first woman of color to perform on the Port-auPrince opera stage and quickly gains a reputation as one of the most talented musical artists and performers in Saint-Domingue. Minette becomes increasingly visible as a public figure and as such, she must grapple with her own understanding of race relations within the colonial social system. This involves navigating complex networks of alliances and conflicts among the various communities in Saint-Domingue, including the free "mulatto" classes, land-owning Blacks, enslaved peoples, poor whites, and the propertied white Creole ${ }^{7}$ classes. As Minette circulates among the various echelons of Port-au-Prince society, other characters also project their own readings of her racial and class status upon her. For her lover Lapointe, a wealthy Black slave owner, Minette's empathy for and political alignment with enslaved people and maroons (channeled in many ways through the knowledge that her mother, Jasmine, was

6 La danse draws its central characters and historical setting from Jean Fouchard's 1955 text, Le Théatre à Saint Domingue, which offers an architectural, social, and political history of the theater in pre-Revolutionary Haiti.

7 In Chauvet's novel, white Creole refers to people of European descent born in the colonies. For more on the history of Creole identity in the francophone Caribbean, see Murdoch, 2001. 
once enslaved herself) - threatens and betrays their social and legal positions as free people of color. For others, such as members of the white Creole classes, Minette's musical talent and accommodation of European feminine style, codes her as white - at the beginning of the novel, a white actress refers to Minette as "tanned" (Chauvet, 1957/2016, p. 64).

Despite the shifting ways her own body is read, Minette is very aware that even as a free woman of African descent within the white colonial social order, she will never be free from racial prejudice and violence. This understanding comes to a head at the end of the novel in which white Creoles, as an act of retaliation against the classes of free people of color who have been asserting their rights to citizenship, systematically murder people of African descent in Port-au-Prince, resulting in the death of Minette's sister Lise and mother Jasmine. Minette is badly wounded in this attack, an injury that will eventually prove fatal. This is not, however, before Minette takes up arms herself, protecting her family and killing two white people who entered their home with murderous intentions. Though Minette lives to see the legal abolition of slavery in Saint-Domingue in 1794, the end of the novel foreshadows the extent to which legacies of colonial socioracial conflict remain very much unresolved in Haiti. Social identity is thus a highly contested space and a site of extreme colonial anxiety in the novel, particularly as race emerged as an increasingly unstable marker of social status in Saint Domingue. From the earliest scenes of La danse, Chauvet is very clear in laying out how the social tensions that build up to the Revolution are tied to colonial constructions of gender, particularly racialized femininity. ${ }^{8}$

8 In her 1999 preface to the second edition, Judith Butler references the discussions she would include
In her description of the production of gender as a discursive ritual, Judith Butler evokes a metaphorics of dress: "Gender is the repeated stylization of the body, a set of repeated acts within a highly rigid regulatory frame..." (1990, p. 44, emphasis mine). The ritualistic practice of self-fashioning underscores, as fashion scholars Jennifer Craik and Elizabeth Wilson suggest, the complex and fraught nature of the relationship between the social world and the material body. Dress, according to Craik (1994), is "an active process or technical means for constructing and presenting a bodily self" (p. 1), an activity and a material item that serves as Wilson (2003) suggests, to connect "the biological body to the social being, and public to private" (p. 2). Clothing calls attention to what Wilson and others have identified as the "dangerous ambiguity" of the body, an organism whose borders and limits are difficult to trace:

Can we really assume that the limits and boundaries of the human body itself are obvious? Does the body end with the skin, or should we include hair, nails?... What of bodily waste materials?...Surely decorative body arts such as tattooing, scarification...should be considered... (Polhemus, 1978, as cited in Wilson, 2003, p. 2)

The "dangerous ambiguity" of the human body takes on a particular set of meanings in the context of the plantation economies of the colonial Atlantic world, in which bodies func-

if she were to rewrite Gender Trouble. Among these is "[...] a discussion on racialized sexuality and, in particular, how taboos against miscegenation (and the romanticization of cross-racial sexual exchange) are essential to naturalized and denaturalized forms that gender takes" (p. xxvii). It is worth pointing out that Caribbean women writers such as Gertrudis Gómez de Avellaneda y Arteaga and Mary Prince have been doing this work since the nineteenth-century, though it is often not recognized as social theory. 
tioned, sometimes simultaneously, as material evidence of one's humanity and one's status as a commodity. C. Riley Snorton (2017) refers to this historical tension in the context of Western racial capitalism as "the transitivity of blackness" (p. 6) - an articulation of the ways in which Blackness is discursively produced through modern logics of trade and material exchange. Similar to Snorton, Steeve O. Buckridge uses a historical approach to examine the role of material things in the formation of structures of social inclusion and exclusion in the Atlantic world. In The Language of Dress: Resistance and Accommodation in Jamaica, 1760-1890 (2004), Buckridge draws on colonial archives to generate a history of women's dress in Jamaica. In this book, Buckridge observes how an exploration of fashion generates new possibilities for understanding the role and representation of women within Jamaica's colonial archives. ${ }^{9}$

Buckridge's study of Jamaican dress and, more specifically, his conceptualization of the term "accommodation" is useful for engaging with the sartorial politics of La danse sur le volcan. Buckridge considers women's dress in the eighteenth- and nineteenth-century Jamaican context as a mode of self-making and as a strategy used by women of African descent for disordering colonial socioracial hierarchies. "Accommodation," as Buckridge defines it, is "...a subtle and complex survival strategy and adaptive mechanism" that means "to embrace or adopt or use as one's own" (p. 7). In his book, Buckridge considers various expressions of accommodation, which range from adopting European modes of femininity as a way to assert one's civil subjecthood,

9 "Material culture facilitates new methods of exploration and interpretation by analyzing the material objects of those who left no written records" (Buckridge, 2004, p. 2). to manipulating European styles through the introduction of African sartorial elements, such as the headtie. ${ }^{10}$ In colonial Jamaica, just as in Saint-Domingue and other colonies of the French and British West Indies, sumptuary laws and articles within the Black Code or Code Noir (legislation developed by the French and British empires designed to govern the relationship between slave owners and enslaved peoples) specifically forbid people of color from wearing certain forms of European dress, such as shoes and hats, as well as luxury textiles, such as crinoline, taffeta, or lace. Accommodation of these fashion items and fabrics by enslaved or free women of African descent was, in many cases, a public rejection of the legal codes designed to protect white racial dominance. This mode of resistance and self-assertion is richly detailed in Chauvet's prose, as she illustrates the complex ways in which sexual desire, fashion, and political visibility are linked in Saint-Domingue society:

Des blanches vêtues de gaules transparentes, aux corsages tout aussi décolletés que ceux des affranchies, passaient amoureusement enlacés aux officiers. "Bouche-en-cour", belle à ravir dans sa jupe ample de couleurs vives, les seins nus sous un transparent corsage de batiste et les cheveux relevés sous son haut madras garni de bijoux était accompagné de l'Intendant du Roi. Elle avait sur les lèvres un sourire triumphant. (Chauvet, 1957/2004, p. 53)

A few white women walked along amourously entwined in the arms of the officers, the bodices of their transparent gaules as plunging as those of the colored women. "Kiss-Me-Lips," devastatingly beautiful in a wide, bright-colored skirt,

10 It is worth noting the creative proximity of adaptation and parody. In recent writing about the 2019 Met Gala's theme, Jonathan M. Square describes the significance of camp within slave societies, when bondspeople would elaborately parody the pretentiousness of the ruling classes during holidays through dress and performance (see Square, 2019). 
her breasts exposed underneath a transparent batiste bodice and her hair pinned up under her jewel-studded madras scarf, was accompanied by the King's Bursar. She wore a triumphant smile on her lips. (Chauvet, 1957/2016, p. 73)

The gaule that Chauvet refers to in her text as worn by both white women and women of color is defined in a footnote as a "Sorte de déshabillé sans taille que portaient les creoles" ("A type of loose undergarment typically worn by Creoles") (Chauvet, 1957/2004, p. 1), which was made explosively popular in the 1780s by none other than Marie Antoinette, whose 1783 portrait by Elisabeth Vigée-Lebrun titled, Marie Antoinette en chemise, caused quite the stir due to its depiction of the queen in what was considered "provincial" dress (London, 2018). The robe de gaulle closely resembles the chemise, a garment that was often worn underneath a dress, which contributes to the somewhat scandalous reputation of this style in European sartorial history. Typically made of thin, white cotton cloth, such as batiste, the robe de gaulle has a loose, gauzy flow and texture. Robes de gaulle were not overly structured like some other women's high fashions of the time and were particularly popular in the French West Indies due to the warm climate.

In the above passage, Chauvet underscores the sensual nature of this style, a garment that instead of hiding the female body, generously and seductively alludes to its form. Here, the character Kiss-Me-Lips's accommodation of European dress, modified by the jewel-studded madras headtie and brightly colored chemise-jupe, serves as a public strategy of claim-making over white colonial power represented by the body of a male government official. Kiss-Me-Lips's "triumphant smile" —which she pointedly "wears" in Kaiama L. Glover's English translation-is, more than her dress, the primary source of colonial racial anxiety. Kiss-Me-Lips's unabashed and cele- bratory existence as a woman of color in public space was a serious threat to the political economy of slavery, which sought to legislate blanches (white women) and affranchies (free women of color) "not only into two races, but into two (racialized) genders" (Tinsley, 2015, p. 137). This anxiety over the femininity and self-fashioning of women of color is clearly articulated in a 1779 regulation passed by the Conseil de Port-au-Prince that sought to further restrict affranchies' access to the material markers of European femininity. Kiss-MeLips's fictional smile haunts the justification for this ordinance:

C'est surtout l'assimilation des gens de couleur avec les personnes blanches dans la manière de se vêtir, le rapprochement des distances d'une espèce à l'autre dans la forme des habillements, la parure éclatante et dispendieuse, l'arrogance qui en est quelquefois la suite, le scandale qui l'accompagne toujours, contre lesquels il est très important d'exciter la vigilance de la police... (Gisler, 1981, p. 94)

It is, above all, the assimilation of coloreds with white people ${ }^{11}$ through dress, the rapprochement of one species to another through clothing style, the glaring and costly finery, the arrogance that often comes with it and the scandal that always follows, to which the vigilance of the police needs to be honed... (Gisler, 1981, p. 94)

Chauvet illustrates the "dangerous ambiguity" (Wilson, 2003) of the dressed bodies of women of color to the white heteropatriachal social order, which scholars such as Steeve O. Buckridge, Omise'eke Natasha Tinsley, and C. Riley Snorton have explored through the lenses of critical race, queer, and transgender

$11 \mathrm{My}$ translation aims to replicate the rhetoric of white supremacy that codes this particular text through a differentiation between "gens de couleur" and "personnes blanches," the word "personne" being reserved for whites. 
theories. Chauvet's re-writing of the Haitian Revolution vibrantly details the relationship between women of color and the material world: the work and the risk of self-fashioning within a social space structured by evolving forms of racial and gendered exclusion. While male citizenship was the basis for both French and Haitian Revolutionary constructions of liberty and individual autonomy, Chauvet's sartorial storytelling underscores the degree to which fashion was itself a social economy of subject-making for women, both within and in spite of patriarchal regimes of power.

\section{Global patterns of exchange: a translational history of madras fabric}

Given the centrality of eighteenth-century sartorial politics to Chauvet's fictional re-telling of the Haitian Revolution, readers of La Danse sur le volcan must navigate a rich inventory of vocabulary related to period European, Caribbean, and West African fashion. Chauvet, whose intended audience for La Danse included French speaking people in metropolitan France, uses footnotes in her text to define and describe certain fashion accessories and textiles that would be unfamiliar to twentieth-century readers, especially those who had never travelled to Haiti or the wider Caribbean. In this way, Chauvet's prose is, at times, both dense and decadent, as the material lives of things-cottons, taffetas, crinolines, the smooth roundness of jewels, the pink, red, and green hues of extravagant ball gowns, silky towers of madras scarves, ripples of lace across exposed skin-animate the novel's pre-Revolutionary imaginings. Chauvet's sartorial poetics and politics thus pose a particular set of challenges for a translator, who must not only transfer La danse into a new linguistic code but also replicate Chauvet's work of bringing colonial Saint-Domingue to life in a new temporal context (Meï, 2018).
In a recent interview, concerning her 2016 English-language translation of La danse sur le volcan, published by Archipelago Press as Dance on the Volcano, Kaiama L. Glover discussed the importance of researching and imagining material things, particularly fabrics and fashions, to her translation praxis. Glover is a celebrated scholar of Haitian literature and an established translator of Haitian fiction. ${ }^{12}$ At one point during the interview with Nathan H. Dize (NHD), Glover (KLG) is asked specifically about her work translating madras - a type of fabric worn as a headtie by many women of color in the novel:

NHD: One of the most fascinating elements of this novel is the attention Chauvet pays to colonial dress, in particular women's clothing like the Madras scarf. Can you talk about the process of conveying this emphasis through translation? How did your training as a literary scholar equip you to manage this task?

KLG: You have highlighted the item of clothing that I paid - that Chauvet obliged me to paythe most attention to in the novel. Clearly Chauvet had done her homework about the ways in which gendered clothing in the $18^{\text {th }}$ century told the stories of different bodies, just as much if not more than other external markers like skin color and hair texture, and such. Clothing in the novel is of paramount importance to assigning status - to keeping people in their place, most often - and to marking the evolution of various characters as their fortunes or attitudes change... The focused attention Chauvet pays to both women and men's clothing throughout the narrative meant that I had to spend quite a lot of time online, searching for images based

12 Glover has translated two books by Frankétienne, Ready to Burst and Ultravocal (published in 2014 and 2016 respectively with Archipelago Books). Glover also translated Hadriana in All My Dreams by René Depestre (published in 2017 with Akhasic Books) and The Wombs of Women: Race, Capitalism, Feminism by Françoise Vergès, which is forthcoming with Duke University Press in 2020. 
on her descriptions so to give myself a better sense of what I was meant to imagine-and to translate-about the appearance of these characters and their costumes. (Dize, 2016)

Glover's response highlights the relationship between literary texts and visual culture, specifically the power of language to generate new social and historical lives for material objects. As the act of translation (and the labor of translators) is often invisible to consumers of foreign literature, Glover's comments about her process also signal the similarities between the cultural positions of fashion and translation. As activities and market products, fashion and translation are often relegated to the realm of the feminine, in which the labor of self-fashioning or translation is viewed as derivative and thus unworthy of critical attention. Feminist scholars from the fields of translation and fashion studies challenge these public misperceptions by showing how translation and fashion are historical strategies of transnational political visibility and self-assertion for women (Tulloch, 2004; Ford, 2015; Collins, 2017; Castro \& Ergun, 2017). While their objects of study differ, a common language emerges at the intersections of feminist fashion and translation studies, one that is characterized by the concept of relation specifically the dialogic relationship between body and garment, translation and source text. Like translations, clothes are haunted by their own (often invisible) narratives of production and like translations, clothes have lives of their own, circulating locally as well as transnationally through the global industrial market. In describing her experience in a costume museum, fashion scholar Elizabeth Wilson remarks upon the anxiety that surfaces when we begin to reflect upon the stories of clothes - where they were made, who made them, who wore them, and why. According to Wilson, these stories make clothing "uneasy territory, since it forces us to recognize that the human body is more than a biological entity. It is an organism in culture, a cultural artefact even, and its boundaries are unclear" (Wilson, 2003, p. 2). In her 1988 article "Gender and the Metaphorics of Translation," feminist translation scholar Lori Chamberlain points to the culture of anxiety around translations due to the way they challenge the heteropatriarchal capitalist binary of production and reproduction. This is why, she insists, that translations are so rigorously policed, their boundaries and definitions so eagerly pinned down: "I would further argue that the reason translation is so overcoded, so overregulated, is that it threatens to erase the difference between production and reproduction which is essential to the establishment of power. Translations can, in short, masquerade as originals, thereby short-circuiting the system" (p. 466). In describing translations as engaging in "masquerade", Chamberlain codes translation sartorially, theorizing, similarly to Wilson, that the policing and maintenance of the hierarchical relationship between cultural production and reproduction is crucial to the preservation of white supremacist, heteropatriarchal, capitalist regimes of power. Translations, like dressed bodies, are dangerously ambiguous. ${ }^{13}$

Glover's version of Dance on the Volcano is, in fact, the second translation of Chauvet's novel to appear in English. An earlier English language rendering by translator Salvator Attanasio

13 The discursive and political synergies between feminist scholarship in translation studies and feminist fashion studies is deserving of further exploration, particularly with regard to the hierarchical, gendered ways in which authorship and reproduction are positioned in relation to one another. The case study discussed in this article serves as an initial attempt to consider the radical authorial possibilities of fashion and translation as historically significant forms of feminist embodied resistance. 
was published in 1959 in New York, just two years after the original release of $L a$ danse. In her introduction to the 2009 English-language translation of Love, Anger, Madness, Haitian-American writer Edwidge Danticat underscores the significance of Dance on the Volcano as it circulated in the United States in the late 1950s and 60s:

La danse sur le volcan, her epic novel on the revolutionary period leading to Haitian independence, was written ten years before this trilogy and was translated and published in the United States, joining Jacques Roumain and two Haitian brothers Philippe and Pierre Thoby-Marcelin, as the only Haitian writers widely available to American readers who, during the occupation period, had been inundated by memoirs written by us military officers who portrayed Haitians as savages, cannibals, and zombies. (Danticat, 2009, p. xii)

Though Chauvet's work may have been increasingly difficult to access in the years to come, the brief history of Haitian literature in English translation that Danticat offers reveals just how critical the Attanasio version was in terms of its potential to disrupt dominant narratives in the us about Haiti and Haitian people, particularly given Chauvet's political commitment to portraying women of African descent as historically complex and powerful human actors. A former World War II army intelligence officer, Attanasio translated over 200 works in his lifetime, including books by Marlene Dietrich, Adolf Hitler, Hans Küng, and Marxist revolutionary Alexandra Kollontai. Described in his New York Times obituary as an "ardent communist" (Attanasio obituary, par. 5), Attanasio's list of translated works is dominated by texts on the subjects of Western theology and philosophy; however, his translations of works by Dietrich, Kollontai, and Chauvet are perhaps indicative of an interest in women's writing on gender and sexual politics. Attanasio and Glover's translations of Chauvet's text differ for a host of reasonsAttanasio's version for one, is syntactically closer to the original French, while Glover's rendering is more fluid and accessible for a contemporary reader of English. However, aside from style, the treatment of material culture within Chauvet's novel is markedly different in the two versions.

The following are excerpts from Chauvet's original text and the two English-language translations. I've selected this particular moment in $\mathrm{La}$ danse because it details Minette's first encounter with Zoé, a Black anti-slavery organizer who brings Minette into her political fold. Here, Minette is recounting to Zoé and several others, how she lost her madras headtie during a terrifying incident in which a white man publicly assaulted her before being killed by Minette's future love interest, Lapointe:

-Tu as perdu ton madras, dit-elle d'une voix basse et comme rentrée. Minette porta la main à ses cheveux.

-Oui, il est tombé pendant que je me battais.

-Te battre, jeune fille, et contre qui? dit le veillard qui n'avait pas encore parlé.

(Chauvet, 1957/2004, p. 83)

"You lost your bandanna," she said in a low voice that sounded tired. Minette ran her hand through her hair. "Yes, it fell off as I was struggling." "You were struggling, child? Against whom were you struggling?" asked the old man. (Chauvet, 1957/1959, p. 83)

"You've lost your madras," she said in a quiet, almost muffled voice. Minette brought her hand to her hair. "Yes, it fell off as I was struggling." "Struggling, young lady—against whom?" asked the old man, who had not yet spoken. (Chauvet, 1957/2016, p. 111)

Reading the three excerpts, it is easy to note the central difference between the Glover (third excerpt) and Attanasio (second excerpt) transla- 


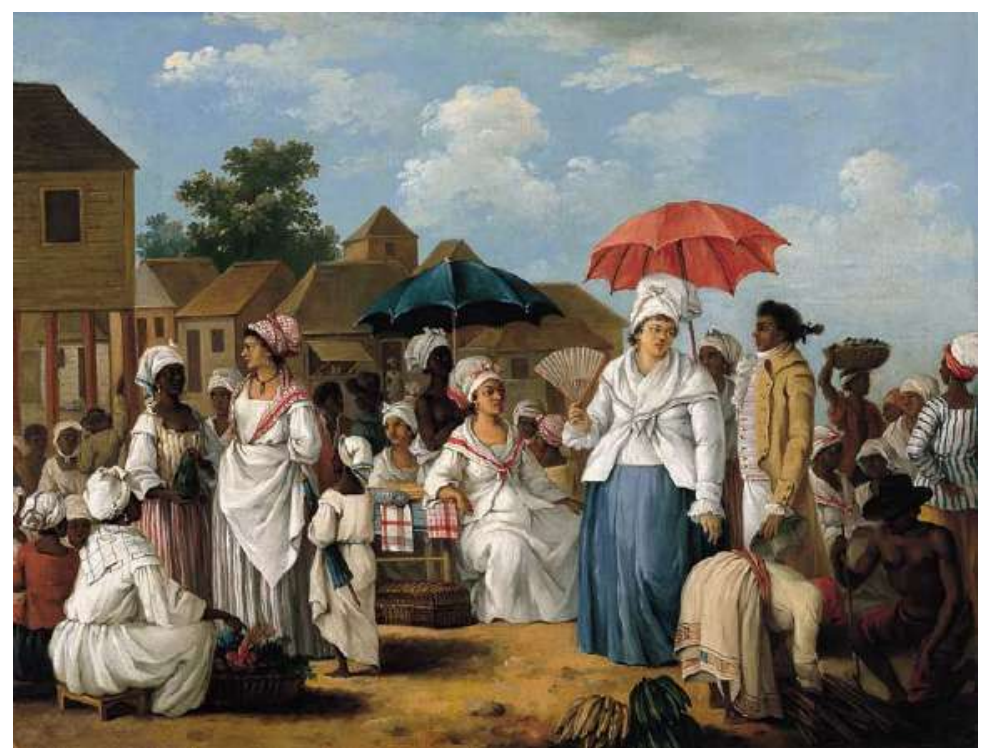

Figure 3. A depiction of madras fabrics being sold and worn by women of various social classes in colonial Saint- Domingue. The Linen Market, Santo Domingo. Augostino Brunias, ca. 1775. Oil on canvas. Madrid: Museo Thyssen-Bornemisza. Republished with permission from the Carmen ThyssenBornemisza Collection.

tions with regard to the material madras, which Attanasio translates as bandanna throughout the novel, while Glover retains the word in English. Madras, a cotton checkered cloth or cotton-silk blend, often dyed red and white in a checked pattern, appears regularly in Chauvet's prose, particularly when she is describing the dress of women characters of color (Figure 3).

In La danse, protagonist Minette often wears a madras headtie, modifying this style to fit both casual and formal occasions. The madras headtie connects Minette sartorially to communities of free women of color as well as enslaved men and women in the novel. One of the significant moments in Minette's awakening to the horrors of the slavery system occurs when an enslaved man runs toward Minette's mother's market stand, where she is selling soaps, madras scarves, and perfumes. Minette's mentor and revolutionary organizer, Joseph Ogé (brother of historical revolutionary figure Vincent Ogé), throws madras scarves and other fabrics over the body of the escapee to hide him from the police who are hot on his trail:

Dix soldats de la maréchaussé passèrent, scrutant les visages et criant la punition qui attendait toute personne qui cacherait des esclaves marrons. Mais que voir, que discerner dans ce tumulte de voix hurlant la réclame, parmi ces centaines de bras foncés brandissant des savons, des madras, des tissus? (Chauvet, 1957/2004, p. 99)

Ten soldiers belonging to the constabulary, patrolled the street, scrutinising people's faces and warned all and sundry of the punishment meted out to persons hiding runaway slaves. But what could they detect or discern in this tumult of voices loudly advertising their wares-among these hundreds of tanned arms brandishing bars of soap, waving bandannas and cloths of all different kinds and colors? (Chauvet, 1957/1959, p. 97)

Ten constabularies passed by, peering into faces and screaming about the punishment awai- 
ting anyone who hid runaway slaves. But what could they possibly see, what could they hope to make out in this tumult of voices calling for customers-out of these hundreds of dark-colored arms brandishing soaps, madras scarves, and fabrics? (Chauvet, 1957/ 2016, p. 131)

Once the area is deemed secure, the man is brought to Jasmine's home where he is dressed in one of her camisoles and outfitted with a madras headtie to disguise him as a woman. So convincing is his disguise that Minette's sister, Lise, greets him as "voisine," the feminine-gendered French word for neighbor. This scene shows how madras cloth, as both a trade item and a gendered fashion accessory, plays a crucial role in anti-slavery organizing and action in Chauvet's imagining of pre-Revolutionary Haiti. This moment also serves as another example of the real threat posed by women of color femininity to the white racial order in Saint-Domingue, in which certain gendered fashion items could be strategically mobilized as a means of escaping the slavery system.

Considered a "global fabric" linking Southeast Asia, West Africa, Latin America, North America, and Europe, the circulation of cotton cloth such as a madras, is an example of what historians such as Giorgio Riello have identified as a mode of material "translation" in which Indian cloths contributed to the "creation of new sacred imagery" through import into foreign contexts (Riello, 2010, p. 7). Due to their mutability and accessibility, Indian cotton cloths were a democratizing force within European sartorial markets in that they "were cheap, but offered a feeling of luxury" (Riello, 2010, p. 11). Checked madras fabric arrived in the seventeenth- century French and English Caribbean colonies through transatlantic and Indian Ocean trade networks established by the French Compagnie des Indes and the British East India Company (Zamor, 2014).
Madras cloth comes originally comes from the Tamil Nadu province in India, of which Madras, now known as Chennai, is the capital city. Tamil Nadu is a region known for its world-class tradition of textile production, particularly the color-fastness of dyed textiles and fabrics. In the seventeenth century, resist-dyed and painted cloth production on the Coromandel Coast in southeast India was crucial to the European spice trade in Indonesia, where Indian cloths were considered even more valuable than precious metals such as gold and copper (Raj, 2013; McGowan, 2019). Madras however was not exclusively produced in India-these trendy cloths were fabricated in the colonial metropoles of France and England during the eighteenth century as part of a global manufacturing shift designed to stimulate industrial growth domestically in the empire. ${ }^{14}$ Indian fabrics such as chintz, cashmere, and madras (and European reproductions of them) were also highly valuable in the slave trade. Bolts of madras fabric often came to New World plantation societies by way of West Africa on European slaving ships (Wilson, 1979). Fabrics and textiles used as currency in the slave trade were known as guinea cloth or indiennes de traite. Madras continued to be a popular Indian export, particularly to Indonesia and Nigeria up through the 1970s, as this fabric features prominently in religious rituals among Torajan communities in Sulawesi (McGowan, 2019) and the Kalabari in Nigeria (Crill, 2015).

In the Atlantic world, madras cloth is closely linked to Afro-diasporic forms of self-fashioning. In Saint Lucia and Dominica, madras fabric is used in the national costume known as the

14 This shift marks the beginning of what we now call "fast fashion," in which cheaper, ready-towear imitations of popular fashions based on Indian designs began circulating widely in European metropoles in the eighteenth century (Smith, 2017). 
wòb dwiyèt (or gwan wòb): a layered, colorful dress worn with a satin foulard and madras headtie (Zamor, 2014). Madras, or bandanna cloth, is also fashioned as part of the national dress for men and women in Jamaica. In 2004, Madras was designated as a national symbol of Saint Lucia in celebration of the nation's $25^{\text {th }}$ year of independence (Saint Lucia National Symbols Awareness Campaign, 2004). In addition to being a fabric used commonly in women's traditional dress in the Caribbean, madras also refers to a headtie style, like the one referenced in previous excerpts from $\mathrm{La}$ Danse. Styled in a variety of ways, the madras headtie has its origins in West African sartorial cultures allowing "African born slave women and their descendants...to maintain links with their African cultural heritage" (Tulloch, 1999, p. 67). In colonies such as Guadeloupe and Martinique, women of color were prohibited from wearing decorative hats, thus making the headtie an important public expression of style and femininity (Zamor, 2014). Zamor (2014) also notes that in Dominica and Saint Lucia, the madras headtie was used as a mode of communication about one's marital status. Depending on how it was tied and the number of peaks created in the cloth, the headtie could convey whether a woman was single, married, or seeking companionship. In colonial Louisiana, Spanish law dictated that women of color had to keep their heads covered at all times, thus the headtie, known as a tignon, became an essential item for appearing in public space (Villalpando, 2015). White Creole women in the colonial Caribbean would also sometimes wear the madras headtie, as this style had become popular among the bourgeois classes due to interest in "exotic forms of dress" that infiltrated the French fashion scene following Napoleon's campaigns in North Africa and the Near East (Buckridge, 2011, p. 87). It should be noted that the headtie style was not limited to women: Toussaint Louverture, the legend- ary military leader of the Haitian Revolution, is said to have hidden his memoirs while in prison in France under his madras headtie (Girard, 2013).

While the historic connections between colonial trade routes and diasporic forms of self-fashioning are well documented, literary translation remains underexamined as a global channel of circulation for the imagined lives of fashion styles and accessories. With regard to Glover and Attanasio's respective representations of madras in an Anglophone context, Lawrence Venuti's distinction between "domesticating" or "foreignizing" strategies in terms of translation praxis is useful. As described in Venuti's now seminal text on Western translation theory, The Translator's Invisibility: A History of Translation (1995), domestication and foreignization are ideological approaches to literary translation into English that designate the practice of either minimizing the foreign elements of a text, such as idiomatic expressions or material references that are culturally bound for target readers (domestication) or preserving and/or accentuating them, thus alerting the reader to the text's existence as a translation (foreignization). Attanasio's translation of madras as bandanna is an example of a form of domestication that has profound implications for how women of color characters, such as Minette and Kiss-MeLips, are read in a us Anglophone context.

Though bandanna cloth is a term used in the Anglophone Caribbean to refer to madras fabric, in the Us, where Attanasio's translation was published and circulated, the word bandanna has a different, though equally complex, cultural history. From the Sanskrit, badhnāti, meaning "to tie" and Hindi bāndhnu, "tie-dyeing," bandanna cloth, like madras, was a very popular Indian- produced handkerchief that circulated widely in the Americas and Europe 
in the eighteenth and nineteenth centuries. Bandanna cloth was also produced domestically in the us during the American Revolution: Martha Washington famously commissioned the production of a linen bandanna with her husband's likeness on it (Kramer, 2017). In her history of the bandanna as a form of Afro-British style, fashion historian Carol Tulloch (1999) describes how popular early twentieth-century representations of the bandanna in the United States, such as those diffused by Hollywood, are examples of the ways in which dominant forms of white femininity continued to be underwritten by Black racial alterity in a post-slavery society. Here, Tulloch points to actress Hattie McDaniel's role as "mammy" in movies such as Gone With the Wind (1939) and Show Boat (1927) in which Black women were portrayed as "devalued and servile," the headtie functioning as a marker of "perennial inferiority" (Tulloch, 1999, p. 65). In the 1940s and 50s, however, the cultural and political significance of the bandanna underwent a significant shift. Where the bandanna served on the silver screen of the 1930s as a marker of Black servitude and androgyny, it was transformed through wwII iconography such as Rosie the Riveter, into a symbol of us American white women's patriotism. The figure of Rosie the Riveter (Figure 4) famously served as a motivating symbol to urge middle-class us American women to leave their homes to work in the military defense industry and in government positions.

In this image, a white woman's bandanna kerchief ties up her hair, visually evoking a sort of femininity defined not by frills, but the business of "hard" work - here the kerchief is used to sartorially link domestic labor to war-time industrial labor. This iconography of course historically erases the labor of Black women in the United States, who had been working outside of their homes since slavery.

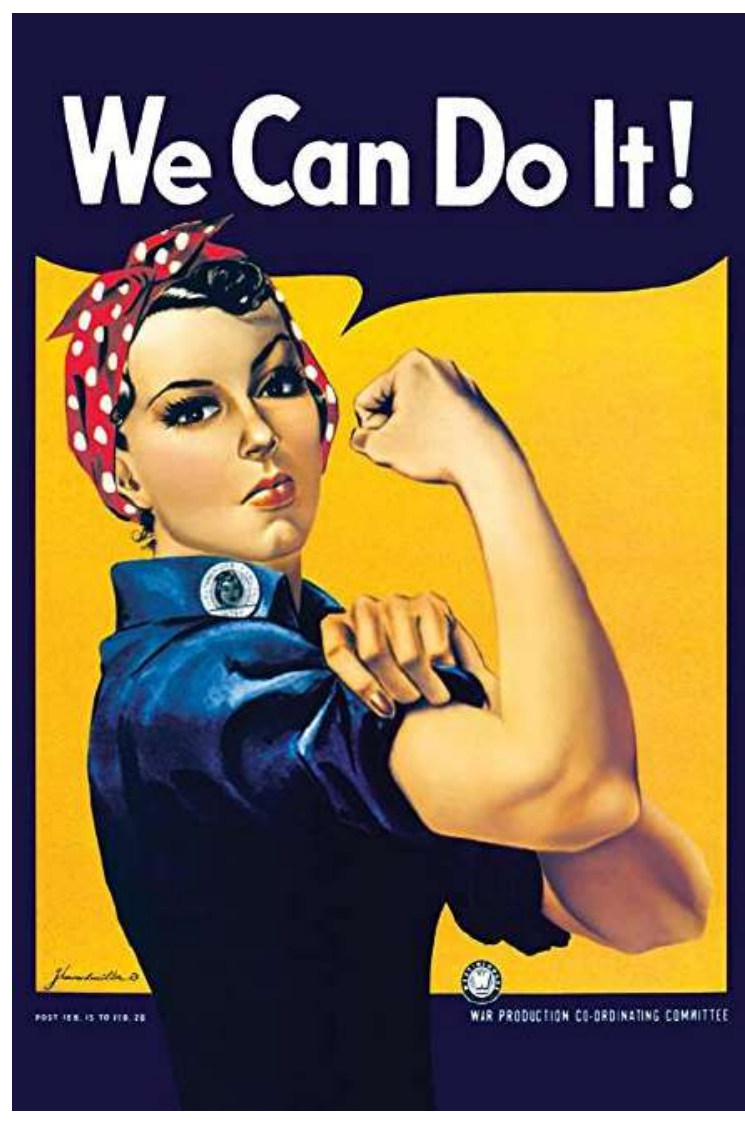

Figure 4. Miller, J. Howard. We Can Do It! (1943). Originally distributed by the War Production Coordinating Committee. Republished with permission from the Division of Political and Military History, National Museum of American History, Smithsonian Institution.

Attanasio's translation - published in the late 1950s - can certainly be read in relation to this shift, his translation locating the character of Minette - a mixed-race woman committed to ending slavery in colonial Saint-Domingue - within an emerging visual and sartorial tradition of us American white women's nationalism and heroism. One can read Attanasio's choice as a deliberate strategy of domestication, given that madras was a word available in English at the time he was translating. According to the 1955 Oxford Universal Dictionary, the second definition for madras reads (after its definition as a city in India): "In full M. handkerchief. a bright-colored handkerchief of silk and 
cotton worn by the Negroes of the W. Indies as a head-dress, formerly exported from Madras" (p. 1184). The definition in the same dictionary for bandanna is "[...] A coloured silk handkerchief with spots left white or yellow by this process [tie-dyeing]. Now used also of cotton handkerchiefs, in which the pattern is produced by chemical agency" (p. 142). While madras, as word in English, clearly evoked the sartorial traditions of the West Indies in its 1955 usage, Attanasio's decision to code Minette's agency within the emerging symbology of us. white women's patriotism obfuscates the specific ways in which racialized gender structured the social economies of Saint-Domingue, which Chauvet labors to show through fashion and material culture.

\section{Towards a sartorial politics of transnational feminist translation}

Attanasio's treatment of fashion in translation is neither unique nor isolated - it is very much connected to the colonial gaze that characterizes travel writings such as Two Years in the French West Indies (1903) by Lafcadio Hearn, in which material expressions of Black femininity are treated as monolithic, one-dimensional, and non-threatening. Attanasio's translation of madras as bandanna not only potentially inscribes Minette's heroism within a history of us propaganda for the military industrial complex, but is evidence of an essentializing perspective that assumes sartorial expressions of Afro-diasporic citizenship are informed by a common ethnic experience and are thus easily translatable across national, historic, and cultural differences. Glover's retention of madras in English not only honors the ethno-cultural specificities of this cloth and style but also pushes back against dominant histories of madras fabric in the United States, which attribute the cultural significance of the cloth to its associations with white male East Coast style, sometimes known as "Ivy League Fashion." Fashion brands such as Ralph Lauren market madras as "the original statement fabric" (Coggins, Ralph Lauren Magazine), its aesthetic "boldness" fitting for a range of styles from "resortwear" to the plaid shirts and sports coats that are now common staples of "preppy" East Coast fashion. us American histories of the cloth, such as the one by Logan Sykes (2015) published in Town \& Country Magazine, suggest that madras fabric first appeared in the colonial United States as a donation to what is now Yale University, from the governor of Madras, slave-trader, and once-president of the British East India Company, Elihu Yale. This version of madras material history completely ignores the widespread fashioning of madras fabric by enslaved and free people of African descent in the United States and Latin America, as well as the use of madras as currency for enslaved people in the transatlantic and Indian Ocean trade systems. Glover's retention of madras in English challenges these popular narratives and in doing so asserts the historical significance of madras as an expression of diasporic Black style.

Published 57 years after Attanasio's version, Glover's translation of Dance on the Volcano serves as a response to growing calls for new narratives about Haiti in the global theatre. Representations of Haiti remain, to use feminist performer-scholar-activist Gina Athena U1ysse's phrasing, "rhetorically and symbolically incarcerated" (Ulysse, 2015, p. 21) —restricted by the persistence of stereotypes that simultaneously alienate and victimize the nation and its communities. The disparagement of Haiti, particularly within North American public media, is deeply connected to the exoticization of Vodou and its exploitation as a cultural metaphor for Black racial inferiority (Glover, 2019). Translation has emerged as a powerful response to the prescriptive and racially prejudicial ways 
in which Haiti, and Vodou, continue to be represented in us popular media and thought. Historian Dr. Kate Ramsey along with scholars of Haiti, Vodou practitioners, and members of KOSANBA (an association dedicated to the study of Haitian Vodou) have successfully petitioned the Library of Congress, as well as major us publishing institutions, to shift their style sheets so that Vodou rather than the offensive "voodoo" is used when referring to the world religion (Meï \& Dize, 2018).

As an Afro-diasporic spiritual tradition, Vodou has been subject to the exploitative and fetishizing mechanisms of white supremacist culture within North America, not in dissimilar ways to other forms of Afro-diasporic expression in science, education, art, politics, and fashion. The co-optation of foreign and 'exotic' cultural expressions within postcolonial literature is a preoccupation of translators such as Glover, who have written on the relationship between translation and conceptualizations of Afro-diasporic citizenship. In a 2019 article titled "Blackness in French: On Translation, Haiti, and the Matter of Race," Glover suggests that while literary translations can allow for new narratives to circulate, this process is historically underwritten by unequal cultural and economic power structures in which the exaggeration of "otherness" continues to be a key selling point for literary texts in translation from Afro-diasporic authors of the Global South. These politics of representation are a major issue for feminist translators who are constantly grappling with what it means to translate, advocate for, and speak with authors from different subject positions. As Glover asks: "How does one represent Global South culture without sensationalizing it, reifying existing racial stereotypes, or censoring its idiosyncrasies in the interest of rendering it more palatable to a world that denies its value(s)?" (p. 28). A possible response to this thorny question can be found in Glover's own treatment of material culture in Dance on the Volcano - specifically her preservation of those sartorial expressions of Afro-diasporic femininity that are critical to Chauvet's representations of women as major actors within the Haitian Revolution. Fashion historian Carol Tulloch's remarks on the diasporic history of Black style, specifically how stories are often coded within sartorial details, are reminiscent of Glover's earlier cited comments on the process of researching and translating material culture within La danse:

The attention to the tiny details that catch your eye; the nuances, inflections and accents that make an impression; the subtle traffic of signs taken out of one code and translated into another; all suggest that black style is not the uniform expression of some unchanging ethnic 'essence', but is best understood as an act of aesthetic agency inscribed into a material world of immense social disparity. (Tulloch, 2004, p. 8)

Tulloch's definition of Afro-diasporic fashion as "an act of aesthetic agency inscribed into a material world of immense social disparity" serves as a powerful articulation of the feminist dimensions of Glover's work as a translator, particularly as she publicly navigates what it means to translate literature for an Afro-diasporic readership within the larger context of a publishing system that devalues and appropriates Black voices from the Global South. In this way Glover's translation of La danse, much like artist Fabiola Jean-Louis's "Re-Writing History" series, opens up a discursive space for considering the kinds of feminist strategies of representation that exist at the intersections of fashion and translation as diasporic expressions of embodied stylization and transformation.

\section{References}

Appadurai, Arjun. (Ed.), (1988). The social life of things: Commodities in cultural perspective 
(2 ${ }^{\text {nd }}$ Ed.). Cambridge, uk: Cambridge University Press.

Attanasio obituary. (1993, June 9). New York Times (Archives). https://www.nytimes. com/1993/06/09/obituaries/salvator-attanasio-79-a-literary-translator.html

Bandanna, -ana. (1953). In William Little, Henry Watson Fowler, Jessie Coulson, \& Charles Talbut Onions (Eds.), The shorter Oxford English dictionary on historical principles (p. 142). Oxford, uK: Clarendon.

Brevik-Zender, Heidi. (2014). Fashioning spaces: Mode and modernity in late nineteenth century Paris. Toronto: University of Toronto Press.

Brown, Bill. (2003). A sense of things: The object matter of American literature. Chicago, IL: University of Chicago Press.

Brunias, Agostino. (ca. 1775). The linen market, Santo Domingo. Oil on canvas. Carmen Thyssen-Bornemisza Collection, Museo Thyssen-Bornemisza, Madrid. (Public domain). http://www.lookenter. com/web/art/thyssen/coleccionctb/ eng/htm/obra 74/ficha.htm

Buckridge, Steeve O. (2004). The language of dress: Resistance and accommodation in Jamaica, 1750-1890. Kingston, Jamaica: University of the West Indies Press.

Butler, Judith. (2007). Gender trouble: Feminism and the subversion of identity. New York, NY: Routledge. (Original work published 1990)

Castro, Olga, \& Ergun, Emek. (Eds.). (2017). Feminist translation studies: Local and transnational perspectives. New York, NY: Routledge.

Chamberlain, Lori. (1988, Spring). Gender and the metaphorics of translation. Signs 13(3), 454-472. http://www.jstor.org/stable/3174168

Cheng, Anne Anlin. (2013). Second skin: Josephine Baker and the modern surface. Oxford, uk: Oxford University Press.

Claude-Narcisse, Jasmine. (1997). Yvonne Hakim Rimpel. Mémoire de fermmes. Portau-Prince, Haiti: Unicef-Haiti. https://
openlibrary.org/books/OL25648960M/ M\%C3\%A9moire_de_Femmes

Coggins, David. (n. d.). Madras: Fierce and fearless. RL Mag. https://www.ralphlauren.com/rlmag/ralph-lauren-the-argument-for-madras.html

Craik, Jennifer. (1994). The face of fashion: Cultural studies in fashion. London, UK: Routledge.

Crill, Rosemary. (Ed.) (2015). The fabric of India. London, UK: Victoria and Albert Museum.

Danticat, Edwidge. (2009). Introduction. In Love, Anger, Madness: a Haitian Triptych by Marie Vieux-Chauvet. (Rose-Myriam Réjouis \& Val Vinokur, Trans.) (pp. vii-xiii). New York, NY: Modern Library.

De la Haye, Amy \& Wilson, Elizabeth. (Eds.). (1999). Defining dress: Dress as object, meaning and identity. Manchester, UK: Manchester University Press.

Dize, Nathan H. (2016, December 22). Haiti in translation: Dance on the volcano by Marie Vieux-Chauvet, An Interview with Kaiama L. Glover. H-Net: Humanities and social sciences online. https://networks.hnet.org/node/116721/discussions/158058/haiti-translation-dance-volcano-marie-vieux-chauvet-interview

Dubois, Laurent. (2016, November). Why Haiti should be at the centre of the age of revolution. Aeon. https://aeon.co/essays/why-haiti-should-be-at-the-centre-ofthe-age-of-revolution

Entwistle, Joanne, \& Wilson, Elizabeth. (Eds.). (2001). Body dressing (dress, body, culture). Oxford, UK: Berg Publishers.

Flotow, Luise von. (1997). Translation and gender: Translating in the 'era of feminism'. Ottawa: University of Ottawa Press.

Ford, Tanisha C. (2017). Liberated threads: Black women, style, and the global politics of soul. Chapel Hill, NC: University of North Carolina Press.

Fouchard, Jean. (1955). Le theatre à Saint Domingue. Port-au-Prince: Imprimerie de l'État. 
Gikandi, Simon. (2011). Slavery and the culture of taste. Princeton, NJ: Princeton University Press.

Girard, Philippe R. (2013). Quelle langue parlait Toussaint Louverture ? Le mémoire du fort de Joux et les origines du kreyòl haïtien. Annales, histoire, sciences sociales, 68e année (1), 109-132. https://www.cairn.info/article. php?ID_ARTICLE=ANNA_681_0109\#

Gisler, Antoine. (1981). L'esclavage aux Antilles Françaises, XVIII à XIX siècle. Paris, France: Karthala.

Glover, Kaiama L. (2013). "Black" radicalism in Haiti and the disorderly feminine: The case of Marie Vieux Chauvet. Small Axe, 17(1(40)), 7-21, http://doi. org/10.1215/07990537-1665407

Glover, Kaiama L. (2019). "Blackness" in French: On translation, Haiti, and the matter of race. L'Esprit Créateur, 59 (No. 2), 2541. http://doi.org/10.1353/esp.2019.0014

Hasbe-Ludt, Erika; Chambers, Cynthia M.; Leggo, Carl. (2009). Life writing and literary métissage as an ethos for our time. New York, NY: Peter Lang Publishing.

Hearn, Lafcadio. (1903). Two years in the French West Indies. New York, NY: Harper and Brothers Publishers.

Hill Collins, Patricia. (2017). Preface: On translation and intellectual activism. In Olga Castro \& Emek Ergun (Eds.), Feminist translation studies: Local and transnational perspectives. New York, NY: Routledge.

Jean-Charles, Régine Michelle. (2017). Naming, claiming, and framing Marie Chauvet. Meridians: Feminism, Race, Transnationalism, 16(1), p. 50-76. http://doi. org/10.2979/meridians.16.1.07

Jean-Louis, Fabiola. (2017). "Marie Antoinette is dead," from the series Re-writing history: Paper gowns and photographs. Archival pigment print, unframed. http://www.fabiolajeanlouis.com/collection
Joseph, Régine. (2015). The letters of Marie Chauvet and Simone de Beauvoir: A critical introduction. In Kaiama L. Glover \& Alessandra Benedicty-Kokken (Eds.), Revisiting Marie Vieux Chauvet: Paradoxes of the postcolonial feminine, Yale French Studies (vol. 128, pp. 9-24). New Haven, ст: Yale University Press.

Kramer, Stephanie. (2017). Bandanna. In Paola Antonelli, Michelle Millar Fisher, \& Luke Baker (Eds.), Items: Is fashion modern? (pp. 51-52). New York, NY: The Museum of Modern Art.

Lehmann, Ulrich. (2000). Tigersprung: Fashion in modernity. Cambridge, ma: The mit Press.

Lewis, Van Dyk. (2003). Dilemmas in African diaspora fashion. Fashion Theory, 7(2), 163-190. http://doi. org/10.2752/136270403778052113

London, Caroline. (2018, January). The Marie Antoinette dress that ignited the slave trade. Racked. https://www.racked. com/2018/1/10/16854076/marie-antoinette-dress-slave-trade-chemise-a-la-reine

Madras. (1953). In William Little, Henry Watson Fowler, Jessie Coulson, \& Charles Talbut Onions (Eds.), The shorter Oxford English dictionary on historical principles (p. 1184). Oxford, UK: Clarendon.

Madras. (1955). In McKechnie (Ed.), Webster's new twentieth century dictionary of the English language unabridged ( $2^{\text {nd }} E d .$, p. 1082). Cleveland, оH: The World Publishing Company.

McGowan, Kaja. (2019). Unfolding the foreign: Mining for sacred Maa' in Torajan local texts. In Ellen Avril (Ed.). Traded treasure: Indian textiles for global markets. Ithaca, NY: Cornell University Press.

Meï, S. (2019, May 20). Madras and the poetics of sartorial resistance. Featured on Age of revolutions [Blog post]. https:// ageofrevolutions.com/2019/05/20/ma- 
dras-and-the-poetics-of-sartorial-resistance-in-caribbean-literature/

Meï, Siobhan. (June, 2018). Review of Vieux-Chauvet, Marie. Danceon the Volcano (Trans. Kaiama L. Glover). sx Salon: The Small Axe Project. http://smallaxe.net/sxsalon/reviews/women-translation-and-haitian-revolution

Meï, Siobhan, \& Dize, Nathan H. (Eds.). (2018, February 17). Vodou in translation: a roundtable on the English language translation of Vodou. H-Net: Humanities and Social Sciences Online. [blog discussion] https://networks.h-net.org/ node/116721/discussions/1397315/vodou-translation-roundtable-english-language-translation-vodou

Miller, J. Howard. (1943). We can do it! Poster originally distributed by the War Production Coordinating Committee. American Museum of National History. https:// americanhistory.si.edu/collections / search/object/nmah_538122

Miller, Monica. (2009). Slaves to fashion: Black dandyism and the styling of Black diasporic identity. Durham, NC: Duke University Press.

Murdoch, H. Adlai. (2001). Creole identity in the French Caribbean novel. Gainesville, FL: Florida University Press.

Raj, S. (2013, November 1-15), Paleacatta Lungis - a way to go in rural heritage development? Madras Musings, 23(4). http:// madrasmusings.com/Vol\%2023\%20 No\%2014/paleacatta-lungis.html

Riello, Giorgio. (2010). The making of a global commodity: Indian cottons and European trade, 1450-1850. World History Studies and World History Education: The Proceedings of the First Congress of the Asian Association of World Historians. https:// warwick.ac.uk/fac/arts/history/people/ staff_index/griello/riello_giorgio.pdf

Saint Lucia National Symbols Awareness Campaign. (2004, January 9). https://web. archive.org/web/20090611095523/ http:/ www.stlucia.gov.lc/pr2004/january/national_symbols_awareness_campaign.htm Sherif, Mary D. (1996). The exceptional woman: Elisabeth Vigée-Lebrun and the cultural politics of art. Chicago, IL: University of Chicago Press.

Simon, Sherry. (1996). Gender in translation: Cultural identity and the politics of transmission. New York, NY: Routledge.

Smith, Blake. (2017). Fast fashion was inspired by Europe's inability to mimic Indian garb. Quartz India. https://qz.com/ india/1120113/fast-fashion-was-inspired-by-europes-inability-to-mimic-indian-garb/

Snorton, C. Riley. (2017). Black on both sides: A racial history of trans identity. Minneapolis, MN: University of Minnesota Press.

Spear, Thomas. (2015). Marie Chauvet: The fortress still stands. In Kaiama L. Glover \& Alessandra Benedicty-Kokken (Eds.), Revisiting Marie Vieux Chauvet: Paradoxes of the postcolonial feminine, Yale French Studies (vol. 128, pp. 9-24). New Haven, ст: Yale University Press.

Square, Jonathan. (2019, September 26). A deep dive into camp within slave societies. Fashioning the self in slavery and freedom [Blog post]. https://fashioningtheself.tumblr.com/slavery-and-camp

Sykes, Logan. (2015, July 2). Print Play: The History of Madras Plaid. Town \& Country Magazine. https://www.townandcountrymag.com/style/fashion-trends/news/ g1413/history-of-madras-plaid/

Tinsley, Omise'eke Natasha Tinsley. (2015). Femmes of color, Femmes de Couleur: Theorizing Black queer feminity through Chauvet's La danse sur le volcan. In Kaiama L. Glover \& Alessandra. Benedicty-Kokken (Eds.), Revisiting Marie Vieux Chauvet: Paradoxes of the postcolonial feminine, Yale 
French Studies (vol. 128, pp.131-145). New Haven, ст: Yale University Press.

Trouillot, Michel-Rolph (1990). Haiti: State against nation, the origins and legacy of Duvalierism. New York, NY: Monthly Review Press.

Tulloch, Carol. (1999). That little magic touch: the headtie. In Amy de la Haye \& Elizabeth Wilson (Eds.), Defining dress: Dress as object, meaning and identity (pp. 63-78). Manchester, UK: Manchester University Press.

Tulloch, Carol. (2004). Black style. London, UK: Victoria and Albert Museum.

Ulysse, Gina Athena. (2015). Why Haiti needs new narratives: A post-quake chronicle. (Nadève Ménard \& Evelyne Trouillot, Trans.). Middletown, ст: Wesleyan University Press.

Venuti, Lawrence. (1995). The translator's invisibility: A history of translation. London, UK: Routledge.

Vergès, Françoise. (1999). Monsters and revolutionaries: Colonial family romance and métissage. Durham, NC: Duke University Press.

Vieux-Chauvet, Marie. (1957). La danse sur le volcan. Paris: Éditions Plon.

Vieux-Chauvet, Marie. (2004). La danse sur le volcan. Paris: Maisonneuve \& Larose et Emina Soleil.

Vieux-Chauvet, Marie. (1959). Dance on the volcano (Salvator Attanasio, Trans.). New York, NY: William Sloane Associates.

Vieux-Chauvet, Marie. (1968). Amour, colère, folie. Paris: Éditions Gallimard.

Vieux-Chauvet, Marie. (2009). Love, anger madness: A Haitian triptych (Rose-Myriam Réjouis \& Val Vinokur, Trans). New York, NY: Modern Library.
Vieux-Chauvet, Marie. (2016). Dance on the volcano (Kaiama L. Glover, Trans.). New York, NY: Archipelago Books.

Vigée-Lebrun, Élisabeth. (1778-1779). Portrait of Marie-Antoinette. 1778-1779. Oil on canvas. Vienna, Austria: Kunsthistorisches Museum (public domain). https://www. khm.at/objektdb/detail/2423/

Villalpando, Rebecca. (2015, February). Portrait of a woman: A study of the social implications of antebellum portraiture in New Orleans. From the exhibition From slave mothers \& Southern belles to radical reformers $\&$ Lost cause ladies: Representing women in the civil war era. http://civilwarwomen.wp.tulane.edu/essays-4/portrait-of-a-womana-study-of-the-social-implications-of-antebellum-portraiture-in-new-orleans/

Vitiello, Joëlle. (1999). Marie Vieux Chauvet. Île-en-île. http://ile-en-ile.org/chauvet/

Walker, Tamara. (2017). Exquisite slaves: Race, clothing and status in colonial Lima. Cambridge, UK: Cambridge University Press.

West, Shearer. (2004). Portraiture. Oxford, UK: Oxford University Press.

Wilson, Elizabeth. (1985). Adorned in dreams: Fashion and modernity New Brunswick, NJ: Rutgers University Press.

Wilson, Elizabeth. (2003). Adorned in dreams: Fashion and modernity ( $2^{\text {nd }}$ Ed.). New Brunswick, NJ: Rutgers University Press.

Wilson, Kax. (1979). A history of textiles. Boulder, co: Westview Press.

Zamor, Hélène. (2014). Indian heritage in the French Creole-speaking Caribbean: A reference to the Madras Material. International Journal of Humanities and Social Science, 4(5), 155-161.

How to cite this article: Meï, Siobhan. (2020). Feminist Translation Matters: Reading Fashion, Materiality, and Revolution in the English-Language Translations of Marie Chauvet's La Danse sur le volcan. Mutatis Mutandis. Revista Latinoamericana de Traducción, 13(1), 159-182. DOI: $10.17533 /$ udea.mut.v13n1a08 